\title{
Tectonic evolution of the Neoproterozoic Tandilia sedimentary cover, Argentina: New evidence of contraction and extensional events in the southwest Gondwana margin
}

\author{
Mariano Hernández ${ }^{a, ~ *, ~ M a r i ́ a ~ J u l i a ~ A r r o u y ~}{ }^{a}$, Nicolás Scivetti a , Juan R. Franzese a \\ José M. Canalicchio ${ }^{\mathrm{b}}$, Daniel G. Poiré ${ }^{\mathrm{a}}$ \\ ${ }^{\text {a } C e n t r o ~ d e ~ I n v e s t i g a c i o n e s ~ G e o l o ́ g i c a s ~-~ C O N I C E T ~-~ F C N y M ~(U N L P), ~ D i a g o n a l ~} 113 N^{\circ} 275$, La Plata, Argentina \\ ${ }^{\mathrm{b}}$ Cementos Avellaneda S.A., Planta San Jacinto, Casilla de Correo 53, Paraje San Jacinto, 7400 Olavarría, Argentina
}

\section{A R T I C L E I N F O}

\section{Article history:}

Received 13 March 2017

Received in revised form

4 August 2017

Accepted 15 August 2017

Available online 18 August 2017

\section{Keywords:}

Fractures

Folding

Normal faulting

Sierras bayas group

La providencia group

Precambrian

\begin{abstract}
A B S T R A C T
At the northwestern portion of the Tandilia System, a detailed structural analysis on the Precambrian sedimentary units exposed in the quarries of the Olavarría-Sierras Bayas area was carried out. These units exhibit deformational structures of several scales, from centimeters to hundreds of meters. The hundreds of meters scale involves E-W- and NW-SE-trending normal faults and NW-SE- and NE-SW-trending contractional folds. The centimeters to meters scale involves veins, joints, normal faults, shear fractures and stylolites, with a prevailing $\sim \mathrm{E}-\mathrm{W}$ to NW-SE trend. All these structures were formed by two major tectonic events. The first was the folding event at $580 \mathrm{Ma}$, with NNE-SSW to NE-SW and NW-SE direction of contraction. The second was the extensional faulting event, given by the widespread NNESSW-directed extension event during the Atlantic Ocean opening (Jurassic-Cretaceous). Both major events would have been controlled by the reactivation of basement anisotropies. These major tectonic events controlled the deformation of the Precambrian sedimentary cover of the Tandilia system, leading to an economically important aspect in the mining development of the Olavarría-Sierras Bayas area.
\end{abstract}

() 2017 Elsevier Ltd. All rights reserved.

\section{Introduction}

The Tandilia System is characterized by its long and complex geological history. Main studies come from the sedimentological and chronostratigraphic analysis of the Neoproterozoic sedimentary cover and from the structural and petrological analysis of the basement (Teruggi and Kilmurray, 1975, 1980; Iñiguez Rodriguez et al., 1989; Dalla Salda et al., 1988; Dalla Salda and Dalziel, 1993, 2006; Poiré et al., 2007, 1989; Poiré and Spalletti, 2005; Gómez Peral et al., 2007; Arrouy et al., 2015). These studies led to many authors to figure out different geodynamic interpretations that have been proposed for the southwest Gondwana configuration (Cawood, 2005; Goscombe and Gray, 2008; Gaucher et al., 2008; Trindade et al., 2006; Rapela et al., 2007, 2011).

Regional-scale structural studies, mainly on the igneousmetamorphic basement (Buenos Aires Complex; Dalla Salda et al., 1988), suggest a basement fault-block deformation, preserving the Precambrian stratigraphy in the downthrown blocks (Iñiguez Rodriguez et al., 1989). Structural studies on the sedimentary cover are local and scarce, but they allowed to differentiate deformational events in the area (Massabie et al., 2008; Rossello et al., 1997; Massabie and Nestiero, 2005).

At the Olavarría-Sierras Bayas area, located at the northwest of Tandilia System (Fig. 1a-b), the Precambrian sedimentary cover has been preserved. This sector constitutes one of the most important mining areas of the Buenos Aires province, and the scattered quarries become key places to carry out field studies.

Given that detailed structural surveys are scarce in this area, being this a helpful tool in the understanding of the tectosedimentary evolution of any region, the aim of this work is to go into detail about the deformational processes that the Olavarría-Sierras Bayas area underwent, by means of the description and interpretation of the multi-scale deformational structures and its relationship with the major tectonic events that happened at the southwest Gondwana margin.

\footnotetext{
* Corresponding author.

E-mail address: mhernandez@cig.museo.unlp.edu.ar (M. Hernández).
} 


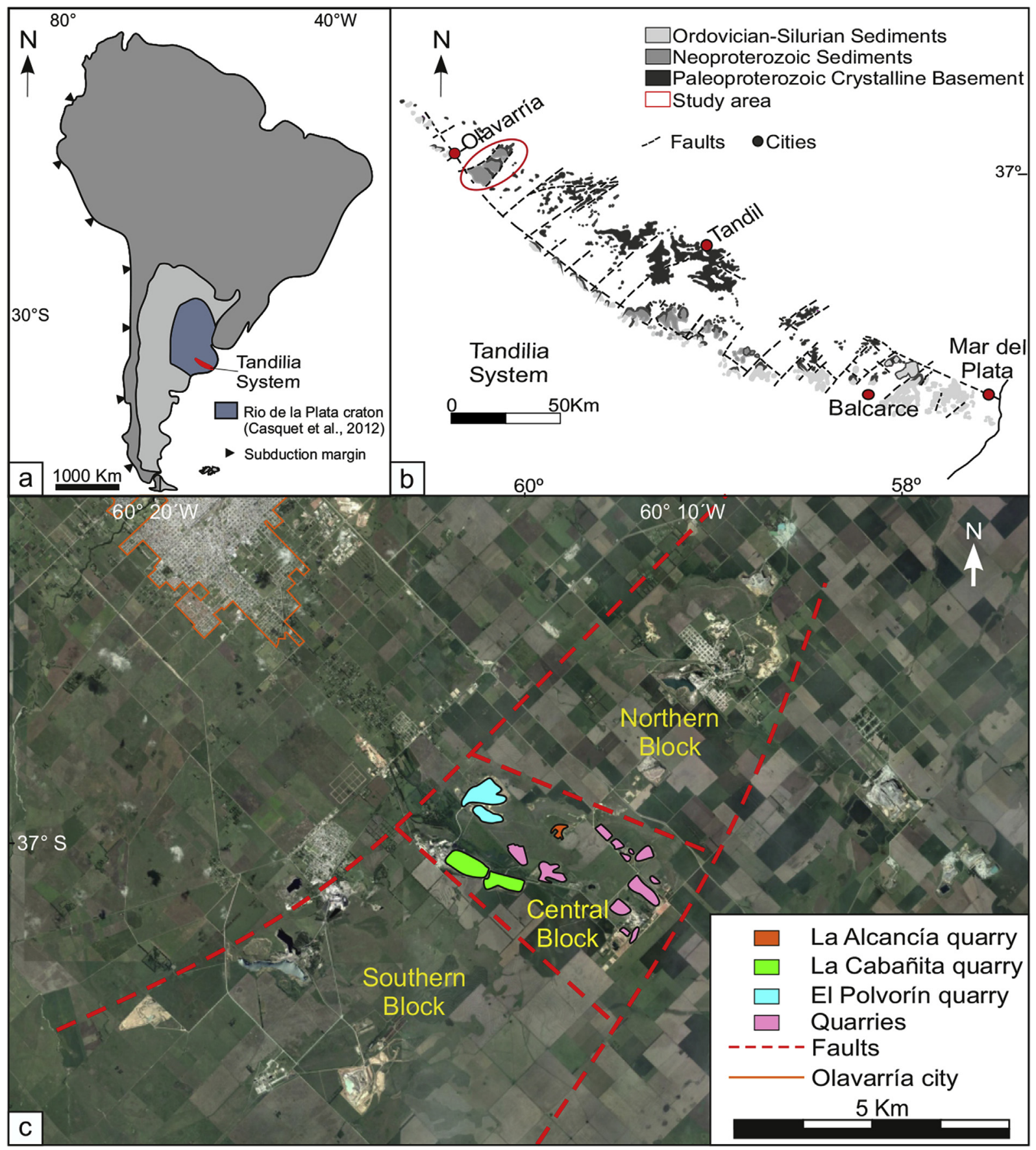

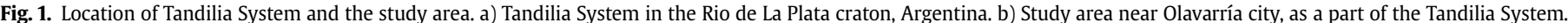

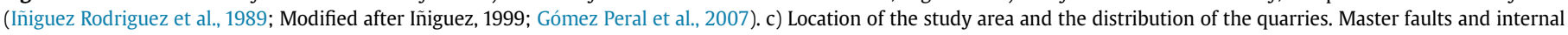
faults marked in dotted lines.

\section{Geological setting}

Tandilia System (Nágera, 1940) is a northwest-southeast trending, $350 \mathrm{~km}$-long, $55 \mathrm{~km}$-width (at its central part) orographic belt, located at the center of Buenos Aires province (Fig. 1a-b), with maximum height of $500 \mathrm{~m}$ a.s.l.. Tandilia System belongs to the Río de la Plata Craton (CRP) (De Almeida et al., 1973, 1976, 2000; Cingolani and Dalla Salda, 2000), which along with other continental blocks formed the southwest part of the
Gondwana continent (Bossi and Cingolani, 2009). The basement rocks (Buenos Aires Complex; Marchese and Di Paola, 1975) are mainly granitoids, orthogneisses and migmatites, with U-Pb SHRIMP zircon ages of 2440-2668 Ma (Cingolani et al., 2002) and Sm-Nd age of $2.6 \mathrm{Ga}$ (Pankhurst et al., 2003). The basement is overlaid by the $\sim 500$ m-thick Neoproterozoic sedimentary successions (Iñiguez Rodriguez et al., 1989; Poiré and Spalletti, 2005; Gómez Peral et al., 2007; Arrouy et al., 2015, Fig. 2), which are the Sierras Bayas Group (SBG) and La Providencia Group (LPG). 


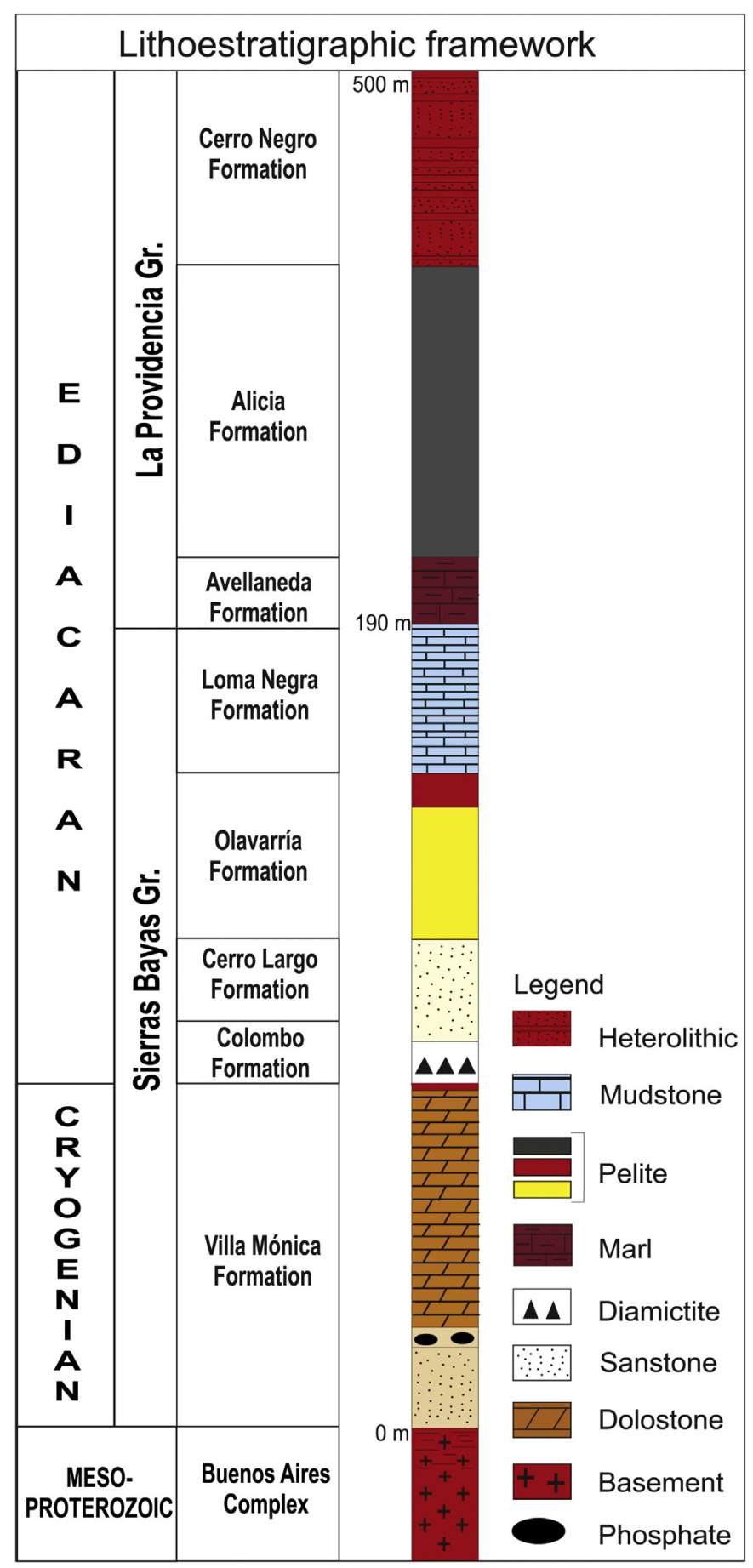

Fig. 2. Representative stratigraphic column of the Sierras Bayas and La Providencia Groups (modified from Arrouy et al., 2015).

Available geochronological data for the Sierras Bayas Group are sparse and somewhat controversial. Detrital zircon ages were reported by Rapela et al. (2007), Gaucher et al. (2008) and Cingolani (2011), being the age of 1150 Ma the youngest one (Rapela et al., 2007). The age of Loma Negra Formation is also controversial. Gaucher et al. (2005) suggested a 542-550 Ma age by the occurrence of a possible Cloudina. Gómez Peral et al. (2007) dated this formation in $\sim 580 \mathrm{Ma}$, considering $\delta 13 \mathrm{C}$ and $87 \mathrm{Sr} / 86 \mathrm{Sr}$ combined trends. Regarding to La Providencia Group, Arrouy et al. (2016) describe typical morphs of Aspidella (related to the 560-550 Ma White Sea Assemblage; Waggoner, 2003) in the Cerro Negro Formation. These units are exposed in the southernmost outcrops of the Río de la Plata Craton and have been correlated with units from Uruguay (Arroyo del Soldado Group; Gaucher et al., 2005), from the Brazilian states of Paraná and Sao Paulo (Aceñolaza and Ciguel, 1987) and with the South African Nama Group (Dalla Salda, 1982 and Gaucher et al., 2005).

Structurally, the basement was affected by large NE-SWtrending faults, with horizontal slip of several kilometers (Teruggi et al., 1973; Dalla Salda et al., 2006).

\subsection{Study area}

The study area is located at the Olavarría-Sierras Bayas area (Fig. 1c), where the structures that affect the Precambrian basement and sedimentary cover are exposed in several quarries. This area is limited by the above mentioned NE-SW-trending fractures, and it is internally divided into three blocks, separated by NW-SE-trending, vertical faults (Iñiguez Rodriguez et al., 1989). These blocks are commonly named as northern, central and southern blocks (Fig. 1c). This work is focused in the central block (Fig. 1c), where La Cabañita, El Polvorín (both property of Cementos Avellaneda S.A) and La Alcancía quarries are located. Neighboring quarry fronts from the northern and southern blocks were taken into account in order to make this work more accurate.

\section{Methods}

Field work was carried out at the central block of the OlavarríaSierras Bayas area, within the El Polvorín, La Cabañita y La Alcancía quarries (Fig. 1c). In this quarries, detailed geological mapping was done, along with stratigraphic and structural surveys. Stratigraphic data comprise the delimitation and classification of formation contacts, formation thickness and bedding orientation (dip direction/dip used as notation). Structural data comprise fracture studies at multiple scales. Large-scale faults were delimited regarding the mapped stratigraphic contacts by means of wells and scattered outcrops, given that the exposure of these structures is very poor. Minor-scale faults were studied on outcrops, regarding its type, geometry, size, orientation and description of the fault zone. Outcrop-scale fractures were studied regarding its type, geometry, orientation and cross-cutting relationships.

Subsurface data were obtained from wells located throughout the area. Surface and subsurface data were integrated using Geographical Information System (GIS) software, allowing the construction of maps and structural profiles. Structural data were analyzed by means of stereographic software (equiangular net, lower hemisphere for planar data. Equiareal net, lower hemisphere for linear data; Marshak and Mitra, 1988).

\section{Results}

In this section we present a description of the structures that affected the Neoproterozoic sedimentary cover of the OlavarríaSierras Bayas area at the central block (Fig. 3). We start by describing the large-scale structures and continue with the more detailed structures at the different quarries. These structures are folds, normal faults of different scales, joints, veins and stylolites.

\subsection{Folds}

Folds are best exposed at the eastern sector of the central block (Fig. 3a). Geological mapping allowed us to define NW-SE-trending, up to $3 \mathrm{~km}$-long, anticlines and synclines with $500-600 \mathrm{~m}$ of 


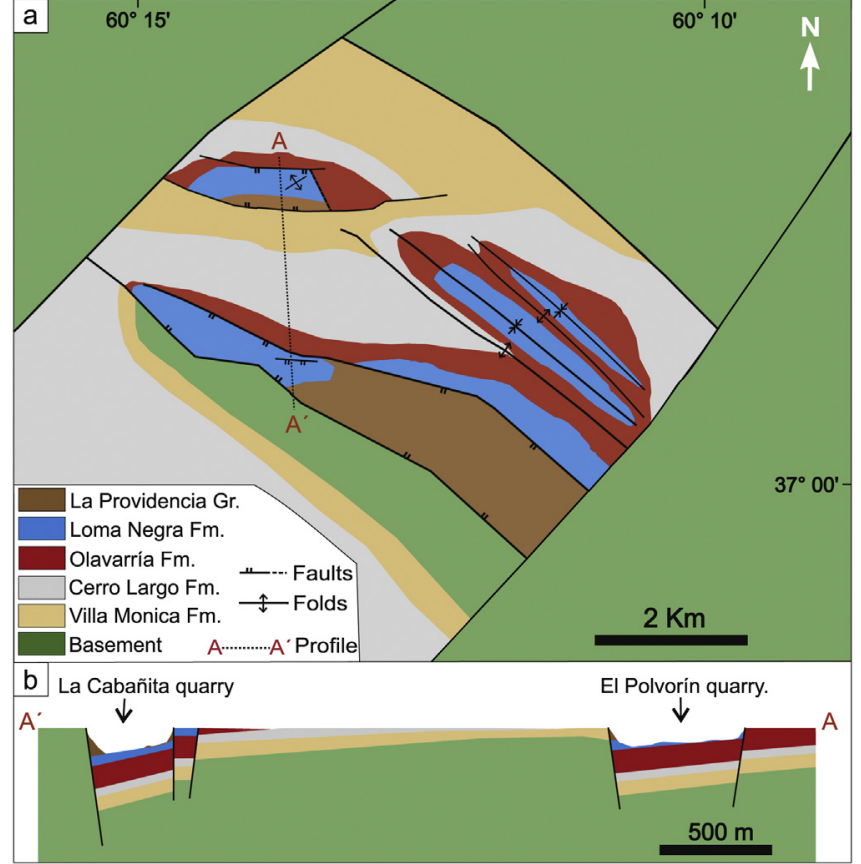

Fig. 3. a) Geologic map of the central block. b) Structural profile comprising the graben structures.

wavelength and an inferred low-plunging fold axis, according to the scarce outcrops and the subsurface data. Few measures on fold limbs in Loma Negra Formation give dip values of $15^{\circ}$, indicating a gentle folding style of SBG. An isolated NE-SW-trending, gentle-toopen anticline affecting the Loma Negra Formation was measured at El Polvorín quarry (Fig. 3a). This fold has a subhorizontal fold axis and an axial trace of $200 \mathrm{~m}$.
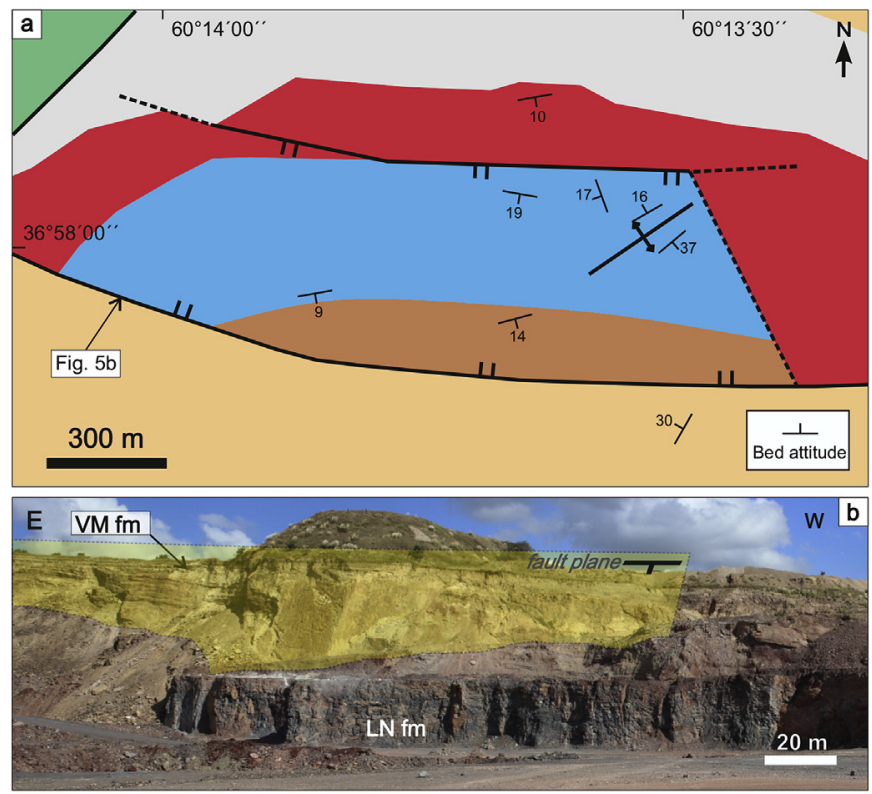

Fig. 4. a) Detailed map of the El Polvorín quarry. See map references in Fig. 3a. b) Southern normal fault (view to the south). The translucent schematic fault plane (with attitude symbol) separates the Loma Negra Formation (lower front view) from the Villa Mónica Formation (back). Loma Negra Formation (LN), Villa Mónica Formation (VM)

\subsection{Large-scale normal faults}

Large normal faults were mapped at the western sector of the central block (Fig. 3a). These faults delimit downthrown blocks in which the upper part of the Neoproterozoic cover are preserved, describing a graben type geometry. These grabens are the El Polvorín and La Cabañita quarries (Fig. 3b). El Polvorín quarry is limited by two E-W-trending, subvertical faults (Fig. 4a). The northern fault put the Olavarría Formation in contact with the Loma Negra Formation and the southern fault put the Loma Negra Formation in contact with the Villa Monica Formation (Fig. 4b), indicating that this latter fault has a larger thrown. In the downthrown block (quarry), the Loma Negra Formation dips to south. La Cabañita quarry is located $1500 \mathrm{~m}$ south of El Polvorín quarry (Fig. 3a). This quarry is limited by two NW-SE-trending subvertical faults, resembling the graben geometry (Fig. 5). The Olavarría and Loma Negra formations and the La Providencia Group are exposed in the downthrown block, in which bedding dips $20^{\circ}-30^{\circ}$ to south.

Hundreds of meters-scale subvertical normal faults were observed affecting both groups (Fig. 5c). The graben shoulders expose the Olavarría Formation to the north and the basement to the south (Fig. 5b), indicating a larger thrown for the southern fault, similar to the El Polvorín quarry.

\subsection{Mesoscale fractures}

Within each quarry, the Loma Negra Formation holds a fracture pattern that includes mainly extensional fractures such as metersscale normal faults, veins and joints, and to a lesser extent, contractional features as shear fractures and stylolites.

\subsubsection{La Cabañita quarry}

At La Cabañita quarry, mostly ESE-WNW-trending extensional fractures were identified in Loma Negra, Avellaneda, Alicia and Cerro Negro formations (Fig. 6e). Commonly found in the Loma Negra Formation, ESE-WNW-trending, 0.5 to $10 \mathrm{~cm}$-wide, upright veins are the main mesostructure (Fig. 6a), sometimes with an en echelon geometry. To a lesser extent, ENE-WSW-trending upright veins are also found. These non-stratabound upright veins are tens of meters-high, with an inferred length equal or larger than the height. The minimum observed spacing is $1-2 \mathrm{~m}$ (Fig. 6a). Bedparallel stylolites of the Loma Negra Formation (Gómez Peral, 2006) are cut by the ESE-WNW- and the ENE-WSW-trending veins, and at the same time, these veins are truncated by the bed-parallel stylolites (Fig. 6a).

Joints exhibit heights of $3 \mathrm{~m}$ or more, in a non-stratabound fashion. These are vertical fractures with several trends, from NESW to NW-SE and NNW-SSE (Fig. 6a). Joints often cut veins, thus, they are relatively younger than veins. These joints were measured in the Loma Negra Formation, but they are common to all units.

Meters to-tens of meters-scale normal faults are observed in the Loma Negra, Avellaneda, Alicia and Cerro Negro formations (Fig. 6b-d). These faults strike E-W to ESE-WNW and dip to NNE (Fig. 6), thus subparallel to the southern main fault that limits the La Cabañita quarry.

\subsubsection{El Polvorín quarry}

At the El Polvorín quarry, veins, joints, shear fractures and stylolites are found (Fig. 7), with scattered exposures. The strikes of these mesostructures are varied, but three main directions prevail as shown in Fig. 7a. The ESE-WNW to NW-SE-trending fractures are mostly veins, similar to those of La Cabañita quarry (Fig. 7b). The $\sim \mathrm{N}-\mathrm{S}$-trending fractures are mostly upright, few millimeterswide veins and joints. Other $\sim \mathrm{N}$-S-trending fractures are thick (up to $3 \mathrm{~cm}$ ), upright veins that exhibit en echelon segments along 

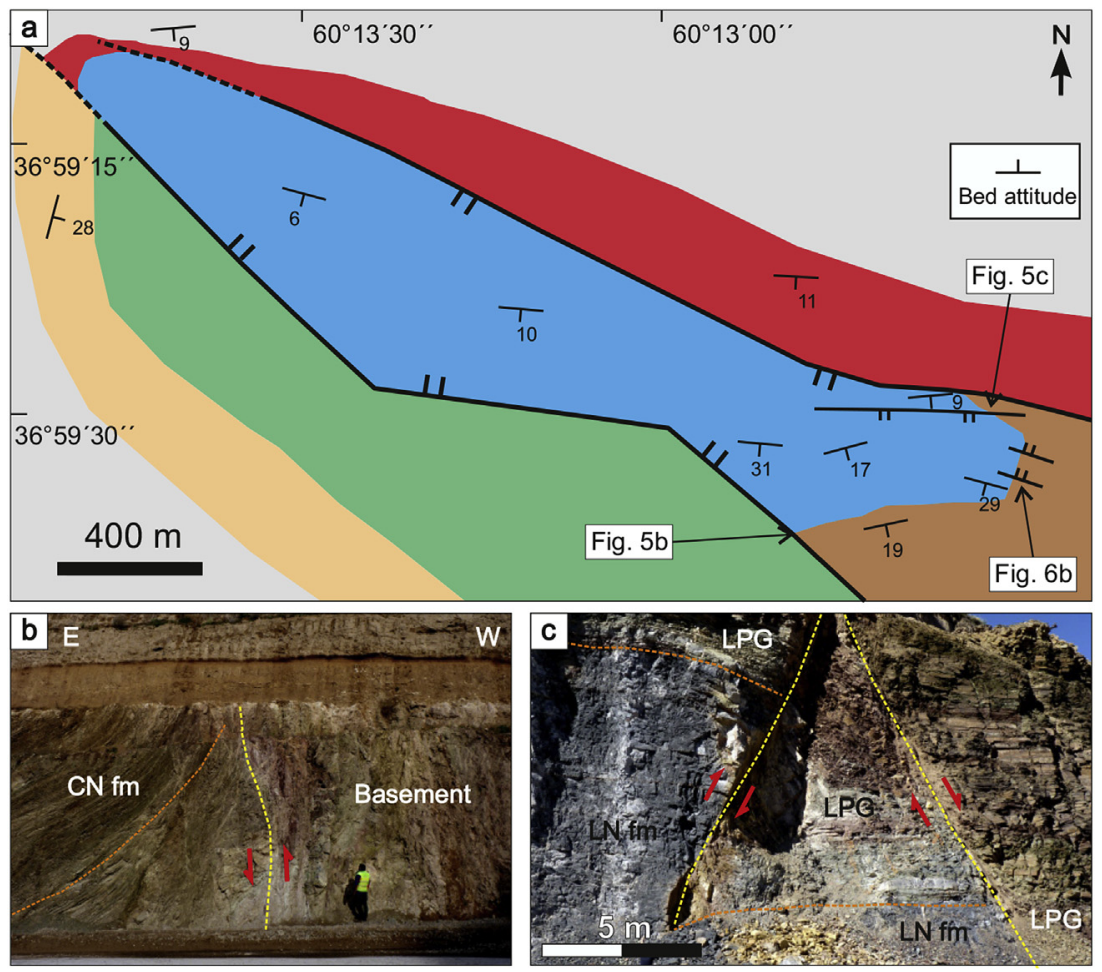

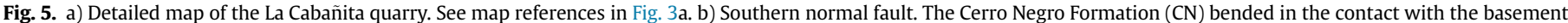
(view to the south; note that the profile view is oblique to the strike of the structures). c) Normal faulting in the interior of the quarry.

its trace, showing dextral shear. These are named here as shear veins (Fig. 7c). The third group on fractures comprises ENE-WSWtrending, upright thin veins (Fig. 7e) and carbonate-filled fractures with dextral displacement of few centimeters (Fig. 7d). These fractures are also referred as shear veins although they look different in appearance to the previous described. Cross-cutting relationships indicate that these fractures are younger than the $\sim \mathrm{N}-\mathrm{S}$-trending ones. Locally, few ENE-WSW- and ESE-WNWtrending, high-angle to bedding stylolites were measured (Fig. 7f). Some veins are cut by these stylolites, indicating that stylolites are younger than veins.

\subsubsection{La Alcancía quarry}

In this quarry the Olavarría Formation crops out. In this unit, few meters-scale, E-W-trending, south-dipping normal faults with few meters of slip were observed (Fig. 8).

\section{Discussion}

The Neoproterozoic sedimentary cover of Tandilia exhibits deformational structures that provide an insight on the processes that took place during the geological evolution of the region in Precambrian times.

The described structures comprise different scales as well as extensional and contractional tectonic regimes. The hundreds of meters-scale structures involve normal faults and contractional folds. The centimeters to meters-scale structures involve extensional structures as veins, joints and normal faults, and contractional mesostructures as shear fractures ("shear veins") and stylolites.

As it is described in the previous section, the multi-scale structures as a whole have common orientations that are repeated all over the area. Thus, it is possible that subparallel structures that represent the same strain have been formed by a common event of deformation. In this way, the structures could be grouped as follows: The $\sim \mathrm{N}$-S-trending dextral shear veins, the ESE-WNW-trending, high-angle to bedding stylolites and the largescale NW-SE-trending folds suggest a NNE-SSW- to NE-SWdirected contraction (Fig. 9a), whereas the ENE-WSW-trending shear veins, the ENE-WSW-trending stylolites and the NE-SWtrending fold (El Polvorín quarry) suggest a $\sim \mathrm{NW}$-SE-directed contraction (Fig. 9b). On the other hand, the ENE-WNW- and ESEWNW-trending veins (La Cabañita quarry), the ESE-WNW- to NWSE-trending veins (El Polvorín quarry) and the E-W- to NW-SEtrending normal faults suggest a $\sim$ NNE-SSW-directed extension (Fig. 9c).

Regarding to contractional or shortening-related tectonic regime, the best expression in the area are folds. NW-SE-trending folds prevail over the NE-SW-trending folds in the SBG. Moreover, the NW-SE-trending synclines have preserved the Loma Negra Formation in the fold troughs, so this fold system represents a type of structural control over the quarries (Figs. 1c and 3a). Both fold systems could be correlated with the second-order folds described by Massabie and Nestiero (2005) in the Sierras Bayas area (located at the northern block). Although in the central block the folds are not interfered, the angle between the trends of both fold systems, which is $70^{\circ}-75^{\circ}$, is similar to the angle of interference described by Massabie and Nestiero (2005), supporting the suggested correlation. Given that evidence of folding in the LPG was not found, the age of folding event could be restricted to $\sim 580 \mathrm{Ma}$ (inferred age for Loma Negra Formation; Gómez Peral et al., 2007), possibly linked to the Gariep-Saldania orogeny (520-580 Ma; Goscombe et al., 2005). According to Massabie and Nestiero (2005), folding would have been controlled by the reactivation of basement anisotropies with NE-SW- and NW-SE-strike. These basement anisotropies would be the $\mathrm{B}$ and $\mathrm{C}$ structural domains, respectively, described by Teruggi et al. (1973) and Dalla Salda et al. (1988). Reactivation of basement anisotropies that produce folding is a common process in 

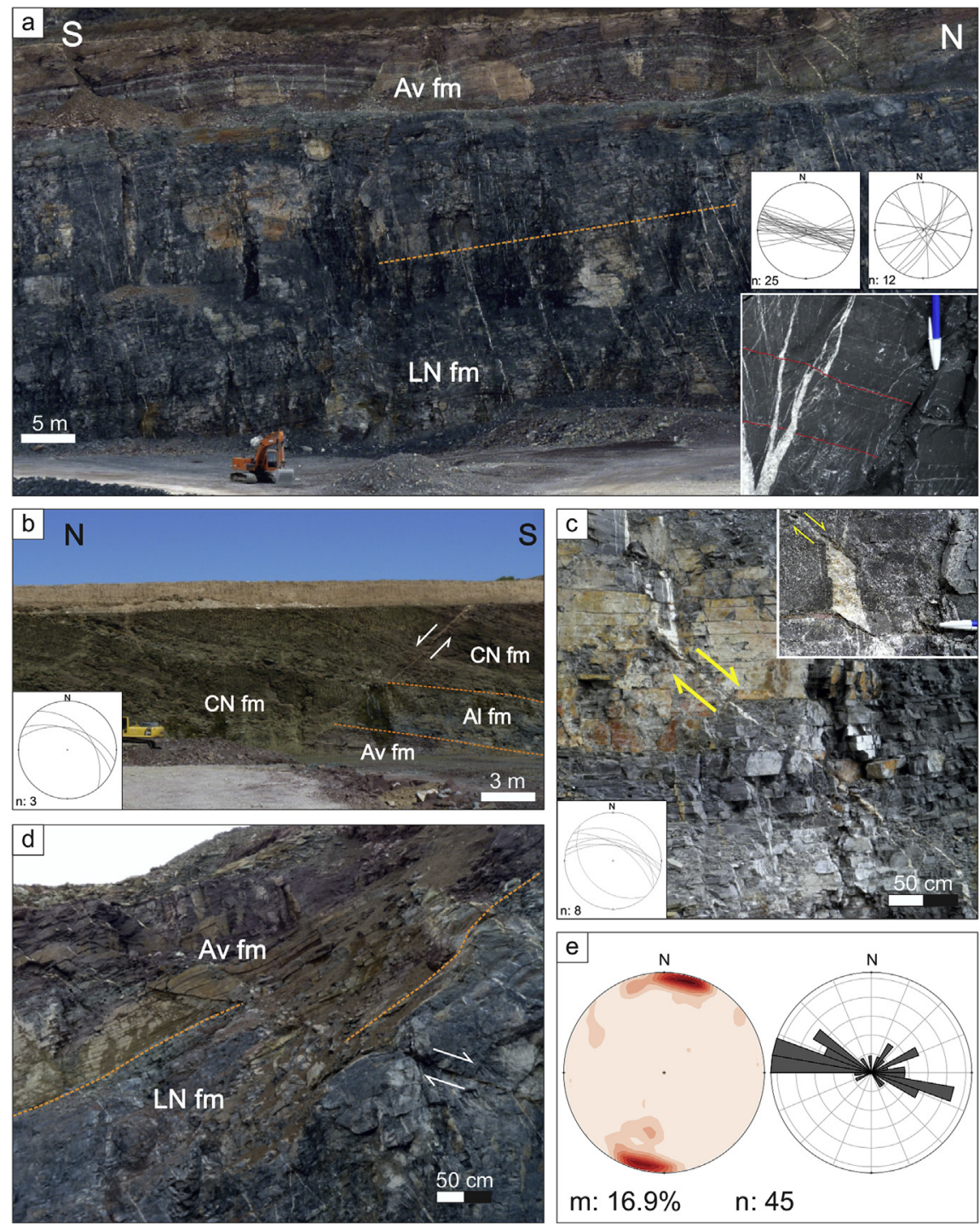

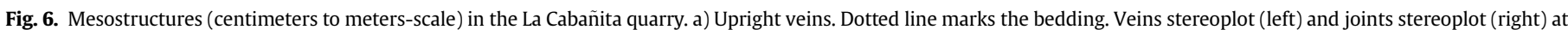

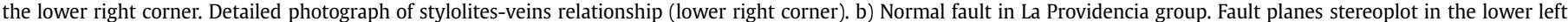

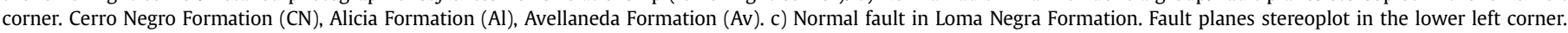

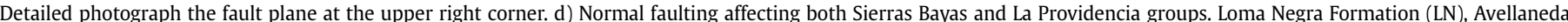

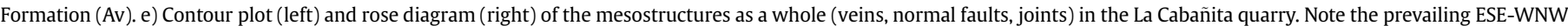
trend.

inverted areas all over the world, where basement-involved folds are produced (Narr and Suppe, 1994; Mitra and Mount, 1998; Paul and Mitra, 2012; among others). Although parallelism between basement structural domains and fold trends is evident, the folding style in the area do not resembles to those of basement-related ones. Thus, one possible inference is that folding on the sedimentary cover could have been produced little before than basement block movements, helped by some detachment of the underlying clay unit (Olavarría Formation). Nevertheless, there is no evidence of such processes in the area, thus this hypothesis remains inconclusive.

Considering that the fold systems and the shear veins indicate similar shortening directions (Fig. 9b-c), the same deformational event is interpreted as responsible of both types of structures. According to the cross-cutting relationships of the shear mesostructures (ENE-WSW-trending shear veins cut the $\sim \mathrm{N}-\mathrm{S}$-trending veins; Fig. 7d), the $\sim \mathrm{NW}$-SE shortening (which would produce the
NE-SW-trending folds) would be the younger event. Massabie and Nestiero (2005) suggest that both fold systems could have formed during one solely event or in two separate events of deformation. Although our data could suggest separate events, this remains inconclusive given the scarce data.

The extensional tectonic regime is represented in the area by several extensional structures of different scales of deformation. The hundreds of meters-scale normal faults, which delimit the quarries, represent a graben geometry, with the downthrown block tilted to S-SE (Fig. 3b). These faults or grabens would represent a second type of structural control over the quarries. As well as the fold systems, faults are parallel to the E-W- and NW-SE-trending structural domains (named A and C, respectively; Teruggi et al., 1973; Dalla Salda et al., 1988). These faults are interpreted to be part of an N-S to NNE-SSW-directed extension phase, in which the basement was involved in the deformation (Fig. 5b). Given the fact that the LPG was affected by the extensional event, this faulting 

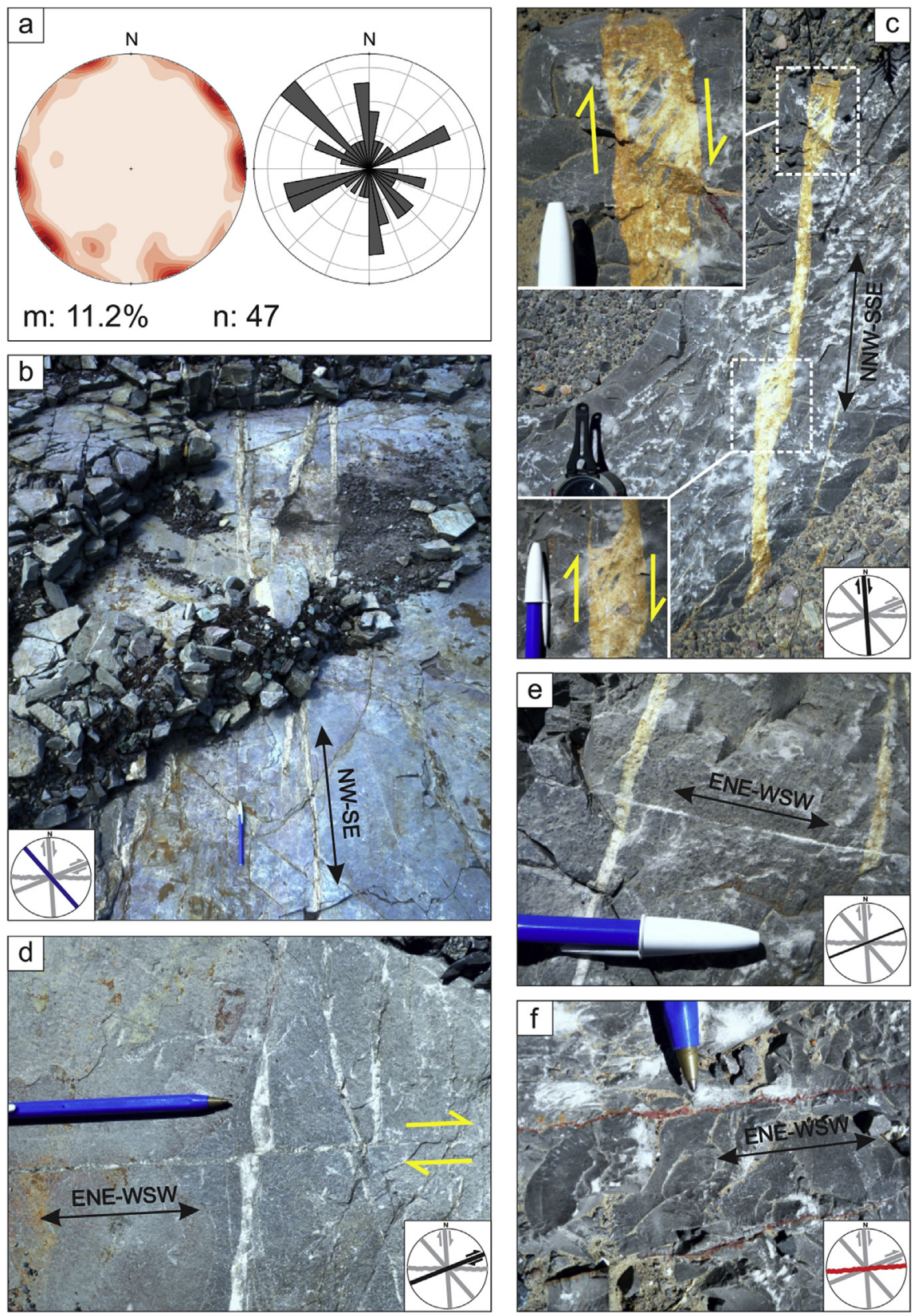

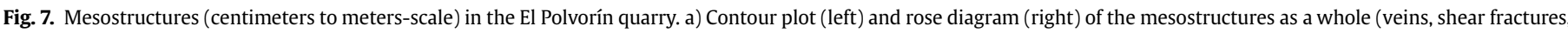

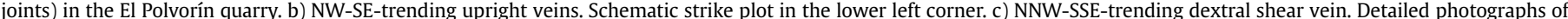

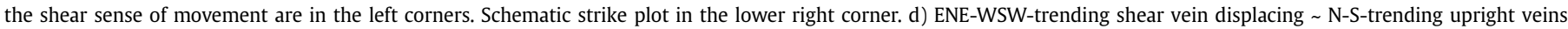

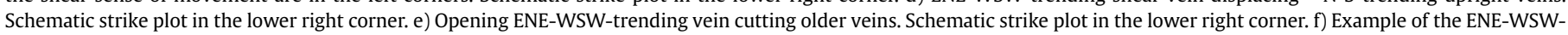
trending, high-angle to bedding stylolite. Schematic strike plot in the lower right corner.

process must be younger that Ediacaran (estimated age for the Cerro Negro Formation of LPG; Arrouy et al., 2016). Two first-order, post-Ediacaran events of deformation has been described in Buenos Aires province: a Permo-Triassic contractional event related to the origin of the Ventania System (Cobbold et al., 1991; Von Gosen et al., 1991; Rossello et al., 1997; Sellés-Martínez, 2001; among others), and the Jurassic-Cretaceous extension event related to the Atlantic Ocean opening and the development of the Salado and Colorado basins (Zambrano, 1980; Uliana et al., 1989).

During the Permo-Triassic contractional event, a NE-SW shortening vector is suggested in Ventania and Tandilia systems, developing local transpression leading to thrust and strike-slip faulting (Rossello et al., 1997; Massabie and Nestiero, 2005; Massabie et al., 2008). Although it is known that inside of a transpressive shear zone local extension could occur (e.g. Sanderson and Marchini, 1984), it is not possible to link the extensional structures (grabens) in the central block to a transpressive system, given that there is no strong evidence about the strike-slip movement on the NE-SW-trending master faults that delimit the three blocks (see Fig. 1c). Another fact is that the NE-SW contraction vector is oriented subparallel to the master faults, which imply a minimum shear component (e.g. Fossen, 2010). Therefore, the grabens of the central block, which indicate an important N-S to NNE-SSW-directed extension, are interpreted as a 


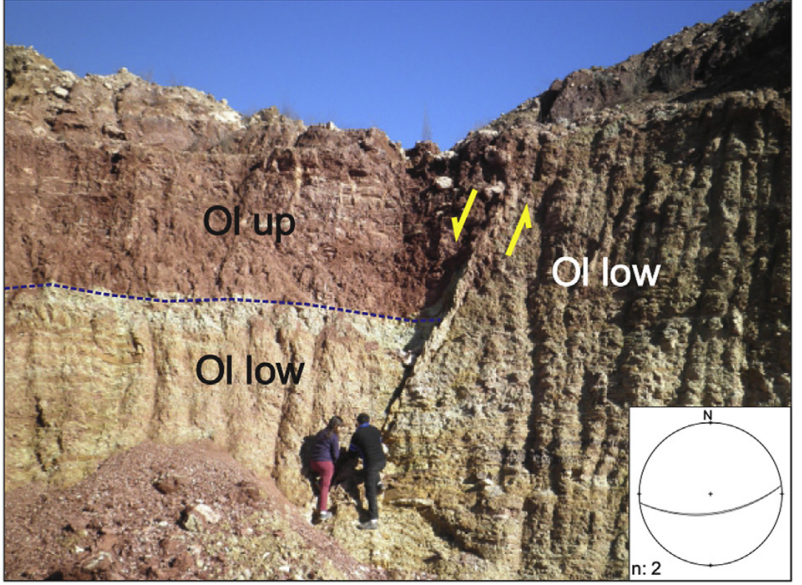

Fig. 8. Normal faults affecting the Olavarría Formation in the La Alcancía quarry. Fault planes stereoplot in the lower right corner. Upper Olavarría Formation (Ol up), Lower Olavarría Formation (Ol Low). explanation. Nevertheless, these veins could be formed (with slightly changes in strike) during the whole deformation of the area.

\section{Conclusion}

Based on the structural analysis carried out in the OlavarríaSierras Bayas area (central block), a chronology of structural and tectonic events that affected the sedimentary cover of Tandilia System is proposed. In summary, the deformational events and its related structures can be described as follows:

1) Some ENE-WSW- and ESE-WNW-trending upright veins are formed during Loma Negra Formation burial, along with the bed-parallel stylolites. Estimated age: $580 \mathrm{Ma}$.

2) Folds, shear fractures (shear veins) and high-angle to bedding stylolites are formed during a contractional event, possibly linked to the Gariep-Saldania orogeny, in which basement anisotropies were reactivated. Approximated shortening direction would be NNE-SSW to NE-SW and NW-SE, according to the ki-

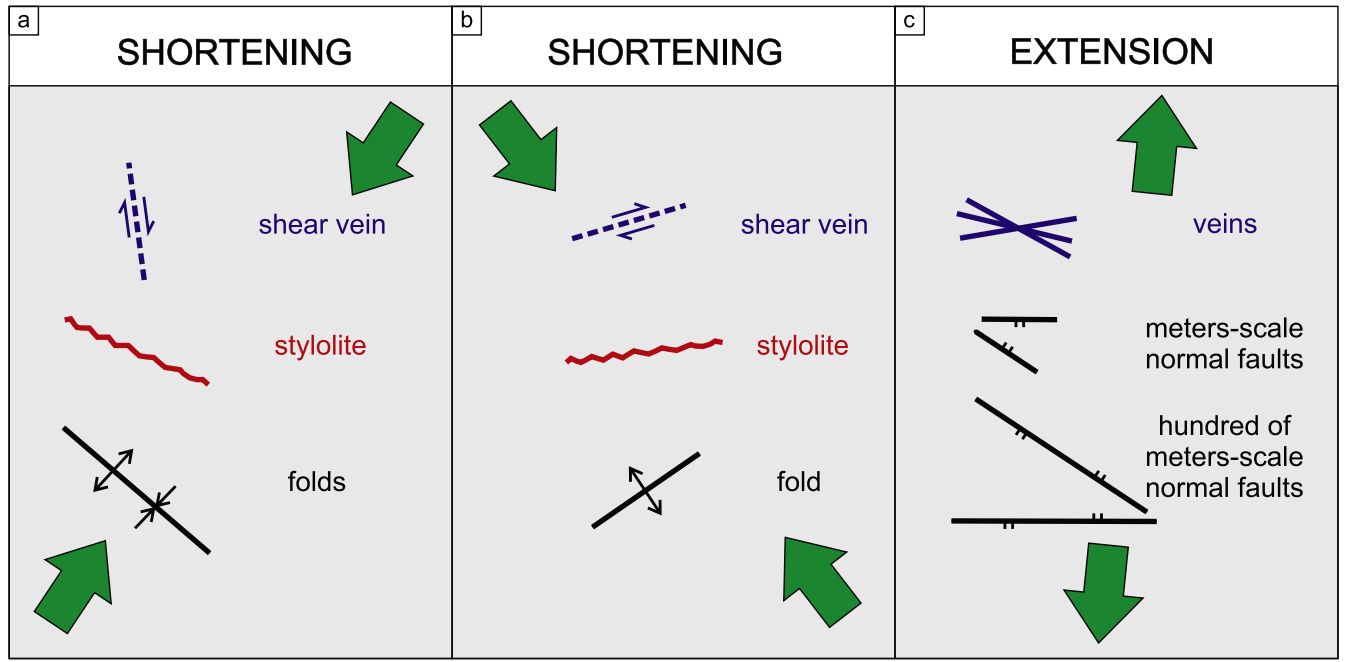

Fig. 9. Schematic structures grouped according to the related tectonic regime and direction of strain (contraction and extension). See text for details.

product of the widespread extension event during the Atlantic Ocean opening, in which the E-W and NW-SE basement structural domains were reactivated in the central block. This interpretation is consistent with the proposal of Massabie et al. (2008) in which breccias of the SBG outcropping in the northern block are ascribed to this extension event.

Small-scale fractures related to extension are common structures in the Earth's crust and could be formed by several processes (Pollard and Aydin, 1988). As well as the contractional mesostructures were related to the folding event, the extension ones are still inconclusive. Regarding to the ESE-WNW- and the ENE-WSWtrending upright veins and the bed-parallel stylolites seen at the La Cabañita quarry, the cross-cutting relationship could indicate that these mesostructures were coeval, both formed during the burial and vertical compaction (i.e. before the folding event). SellésMartínez (1994) has a similar interpretation, suggesting that all these veins are hydraulic fractures formed during diagenesis. On the other hand, given that the ESE-WNW-trending upright veins are subparallel and are spatially related to the meters-scale normal faults, they could also be interpreted as being part of the same extension event of deformation (i.e. Atlantic Ocean opening). Thus, these veins are controversial, being both processes a possible nematic of mesostructures and the trend of both fold systems. Estimated age: $520-580$ Ma.

3) Meters-to hundreds of meters-scale normal faults, and possibly new ESE-WNW-trending upright veins, formed by an N-S to NNE-SSW-directed extension. This event is correlated with the widespread Atlantic Ocean opening during Jurassic-Cretaceous times.

Finally, it is confirmed that the present morpho-structural configuration of Tandilia System included a series of deformational events that acted on an episodic way from Precambrian times until the Mesozoic, in which the reactivation of basement anisotropies played a key role during its complex tecto-sedimentary evolution.

\section{Acknowledgements}

The authors are especially grateful to Cementos Avellaneda S.A. for the financial support and logistics during the field work. We would also like to show our gratitude to Dr. Lucia Gomez Peral and Dr. Sebastian Richiano for their assistance in the field. Dr. SellésMartínez and an anonymous reviewer are thanked for their 
constructive comments and Victor Ramos for editorial handling.

\section{References}

Aceñolaza, F.G., Ciguel, J.H.G., 1987. Análisis comparativo entre las Formaciones Balcarce (Argentina) y Furnas (Brasil). X congreso Geológico Argentino, Actas, San Miguel de Tucumán, pp. 299-305.

Arrouy, M.J., Poiré, D.G., Gómez Peral, L.E., Canalicchio, J.M., 2015. Sedimentología y estratigrafía del grupo La Providencia (Nom. Nov.): cubierta Neoproterozoica, Sistema de Tandilia, Argentina. Lat. Am. J. Sedimentology Basin Analysis 22 (2), $1-38$.

Arrouy, M.J., Warren, L.V., Quaglio, F., Poiré, D.G., GuimarãesSimões, M., Boselli, M.R., Gómez Peral, L.E., 2016. Ediacaran discs from South America: probable softbodied macrofossils unlock the paleogeography of the Clymene Ocean. Sci. Rep. 6 (30590), 1-10.

Bossi, J., Cingolani, C., 2009. Extension and general evolution of the Río de la Plata Craton. In: Gaucher, C., Sial, A.N., Halverson, G.P., Frimmel, H.E. (Eds.), Neoproterozoic-Cambrian Tectonic, Global Change and Evolution: a Focus on Southwester Gondwana. Developments in Precambrian Geology, vol. 16, pp. 73-83.

Cawood, P., 2005. Terra Australis Orogen: Rodinia breakup and development of the Pacific and Iapetus margins of Gondwana during the Neoproterozoic and Palaeozoic. Earth Sci. Rev. 69, 249-279.

Cingolani, C., 2011. The Tandilia System of Argentina as a southern extension of the Río de la Plata craton: an overview. Int. J. Earth Sci. 100, 221-242.

Cingolani, C.A., Dalla Salda, L., 2000. Buenos Aires cratonic region. In: Cordani, U. Milani, E., Thomaz Filho, A., Campos (Eds.), Tectonic Evolution of South America. Proceeding 31st International Geological Congress. Rio de Janeiro, pp. 139-146.

Cingolani, C.A., Hartmann, L.A., Santos, J.O.S., McNaughton, N.J., 2002. U-Pb SHIMP dating of zircons from the Buenos Aires Complex of the Tandilia Belt, Rio de LaPlata Craton, Argentina. In: Actas XV CongresoGeológicoArgentino. El Calafate.

Cobbold, P.R., Gapais, D., Rossello, E.A., 1991. Partitioning of transpressive motions within a sigmoidal foldbelt: the Variscan Sierras Australes, Argentina. J. Struct. 13 (7), 743-758.

Dalla Salda, L., 1982. Nama - La Tinta y el inicio de Gondwana. Acta Geologica Lilloana XVI:1.

Dalla Salda, L., Dalziel, W.D., 1993. Evolución paleogreografica del occidente de Gondwana durante el Neoproterozoico-Paleozoico Medio. Primer simposio internacional del Neoproterozoico-cambrico de la cuenca del plata, Uruguay. Tomo I.

Dalla Salda, L., Bossi, J., Cingolani, C., 1988. The Rio de la Plata cratonic region of southwestern Gondwana. Episodes 11 (4), 263-269.

Dalla Salda, L., Spalletti, L., Poiré, D., De Barrio, R., Echeveste, H., Benialgo, A., 2006. Tandilia. Ser. Correlación Geol. 21, 17-46.

De Almeida, F.F.M., Amaral, G., Cordani, U.G., Kawashita, K., 1973. The precambrian evolution of South American cratonic margin south of the Amazon River. In: Nairn, A.E.M., Stehli, F.G. (Eds.), The Ocean Basins and Margins, vol. 1. The South Atlantic, Plenum, New York, pp. 411-446.

De Almeida, F.F.M., Hasui, Y., Brito Neves, B.B., 1976. The Upper Precambrian of South America, vol. 7. Boletim Instituto Geociencias, Universidade de Sao Paulo, pp. $45-80$.

De Almeida, F.F.M., Brito Neves, B.B., Carneiro, C.D.R., 2000. The origin and evolution of the south American platform. Earth Sci. Rev. 50, 77-111.

Fossen, H., 2010. Structural Geology. Cambridge University Press, Cambridge.

Gaucher, C., Poiré, D.G., Gómez Peral, L.E., Chiglino, L., 2005. Litoestratigrafía, bioestratigrafía y correlaciones de las sucesiones sedimentarias del Neoproterozoico-Cámbrico del Cratón del Río de La Plata (Uruguay y Argentina). Lat. Am. J. Sedimentology Basin Analysis 12 (2), 145-160.

Gaucher, C., Finney, S.C., Poiré, D.G., Valencia, V.A., Grove, M., Blanco, G., Pamoukaghlián, K., Gómez Peral, L., 2008. Detrital zircon ages of Neoproterozoic sedimentary successions in Uruguay and Argentina: insights into the geological evolution of the Río de la Plata Craton. PrecambrianResearch 167, 150-170.

Gómez Peral, L.E., 2006. Relación entre las estilolitas y la diagénesis en las unidades carbonáticas del Grupo Sierras Bayas, Neoproterozoico, Argentina. Acta de resúmenes: IV Congreso Latinoamericano de Sedimentología y XI Reunión Argentina de Sedimentología, 110. Bariloche, Argentina.

Gómez Peral, L.E., Poiré, D.G., Strauss, H., Zimmermann, U., 2007. Chemostratigraphy and diagenetic constraints on neoproterozoic carbonate successions from the Sierras Bayas group, Tandilia system, Argentina. Chem. Geol. 237, 127-146.

Goscombe, B.D., Gray, D.R., 2008. Structure and strain variation at mid-crustal levels in a transpressional orogen: a review of Kaoko Belt structure and the character of west Gondwana amalgamation and dispersal. Gondwana Res. 13, 45-85.

Goscombe, B., Gray, D., Armstrong, R., Foster, D.A., Vogl, J., 2005. Event geochronology of the Pan-African kaoko belt, Namibia. Precambrian Res. 140, 1-41.
Iñiguez Rodriguez, A.M., del Valle, A., Poiré, D.G., Spalletti, L.A., Zalba, P.E., 1989 Cuenca precámbrica-paleozoica inferior de Tandilia, Provincia de Buenos Aires. Serie Correlación Geológica. In: Chebli, G., Spalletti, L.A. (Eds.), Cuencas Sedimentarias Argentinas, vol. 6. Universidad Nacional de Tucumán, Instituto Superior de Correlación Geológica, pp. 245-263.

Marchese, H.G., Di Paola, E., 1975. Miogeosinclinal tandil. Rev. Asoc. Geol. Argent. 30 (2), 161-179.

Marshak, S., Mitra, G., 1988. Basic Methods of Structural Geology. Prentice-Hall, Inc.

Massabie, A.C. Nestiero, O.E., Sanguinetti, A.S., 2008. Brechas y microbrechas cohesivas en cuarcitas de la sierra de Buenos Aires. Similitudes, diferencias y aproximaciones a su vinculación tectónica. Rev. Asoc. Geol. Argent. 63 (2), 163-171.

Massabie, A.C., Nestiero, O.E., 2005. La estructura del Grupo Sierras Bayas en el sector norte de las Sierras Septentrionales de Buenos Aires. Rev. Asoc. Geol. Argent. 60 (1), 135-146.

Mitra, S., Mount, V.S., 1998. Foreland basement-involved structures. AAPG Bull. 82, 70-109.

Nágera, J.J., 1940. Historia física de la Provincia de Buenos Aires. Tandilia, vol. 1. Universidad Nacional de La Plata. La Plata, 24.

Narr, W., Suppe, J., 1994. Kinematics of basement-involved compressive structures. Am. J. Sci. 294, 802-860.

Pankhurst, R.J., Ramos, A., Linares, E., 2003. Antiquity of the Río de la Plata craton in Tandilia, southern Buenos Aires province, Argentina. J. S. Am. Earth Sci. 16, 5-13.

Paul, D., Mitra, S., 2012. Controls of basement faults on the geometry and evolution of compressional basement-involved structures. AAPG Bull. 96, 1899-1930.

Poiré, D.G., 1989. Stromatolites of the Sierras Bayas group, upper proterozoic of Olavarría, Sierras septentrionales, Argentina. StromatoliteNewsletter 11, 58-61.

Poiré, D.G., Spalletti, L.A., 2005. La cubierta sedimentaria precámbrica/paleozoica inferior del Sistema de Tandilia. In: De Barrio, R.E., Etcheverry, R.O. Caballé, M.F., Llambías, E.J. (Eds.), Geología y Recursos Minerales de la provincia de Buenos Aires. Relatorio del XVI Congreso Geológico Argentino, La Plata, pp. $51-68$.

Poiré, D.G., Gaucher, C., Germs, G., 2007. La superficie "Barker" y su importancia regional, Neoproterozoico del Cratón del Río de La Plata. VI Jornadas Geológicas y Geofísicas Bonaerenses, Actas, 36. Mar del Plata, Argentina.

Pollard, D.D., Aydin, A.A., 1988. Progress in understanding jointing over the past century. Geol. Soc. Am. Bull. 100, 1181-1204.

Rapela, C.W., Pankhurst, R.J., Casquet, C., Fanning, C.M., Baldo, E.G., GonzálezCasado, J.M., Galindo, C., Dahlquist, J., 2007. The Río de la Plata Craton and the assembly of SW Gondwana. Earth Sci. Rev. 83, 49-82.

Rapela, C.W., Fanning, C.M., Casquet, C., Pankhurst, R.J., Spalletti, L., Poiré, D., Baldo, E.G., 2011. The Rio de la Plata craton and the adjoining Pan-African brasiliano terranes: theirorigins and incorporation into south-west Gondwana. Gondwana Res. 20, 673-690.

Rossello, E., Massabie, A., Lopez-Gamundi, O., Cobbold, P., Gapais, D., 1997. Late paleozoic transpression in Buenos Aires and northeast patagonia ranges, Argentina. J. S. Am. Earth Sci. 10 (5-6), 389-402.

Sanderson, D.J., Marchini, W.R.D., 1984. Transpression. J. Struct. Geol. 6, 449-458.

Sellés-Martínez, J., 1994. Lineamientos estructurales y evolución extensional de la plataforma neoproterozoica-Eopaleozoica de las Sierras Septentrionales de la Provincia de Buenos Aires (Argentina). Rev. Bras. Geociencias 23 (3), 289-295.

Sellés-Martínez, J., 2001. Geología de la Ventania (Provincia de Buenos Aires, Argentina). J. Iber. Geol. 27, 43-69.

Teruggi, M.E., Kilmurray, J., Dalla Salda, L., 1973. Los dominios tectónicos de la región de Tandilia. An. Soc. Científica Argent. 295 (1-2), 81-94.

Teruggi, M.E., Kilmurray, J.O., 1975. Tandilia. $6^{\circ}$ Congreso Geológico Argentino. Relatorio $57-77$.

Teruggi, M.E., Kilmurray, J.O., 1980. Sierras Septentrionales de la provincia de Buenos Aires. In: Turner, J. (Ed.), Geología Regional Argentina, vol. 2. Academia Nacional de Ciencias, Córdoba, pp. 919-965.

Trindade, R.I.F., D'Agrella-Filho, M.S., Epof, I., Brito Neves, B.B., 2006. Paleomagnetism of Early Cambrian Itabaiana mafic dikes (NE Brazil) and the final assembly of Gondwana. Earth Planet. Sci. Lett. 244, 361-377.

Uliana, M.A., Biddle, K.T., Cerdan, J., 1989. Mesozoic extension and the formation of Argentine sedimentary basins. In: Tankard, A.J., Balkwill, M.R. (Eds.), Extensional Tectonics of the North Atlantic Margins, vol. 46. American Association Petroleum Geologists Memoir, pp. 599-614.

Von Gosen, W., Buggisch, W., Krumm, S., 1991. Metamorphism and deformation mechanisms in the Sierras Australes fold and thrust belt (Buenos Aires province. Argentina). Tectonophysics 185, 335-356.

Waggoner, B., 2003. The Ediacaran biotas in space and time. Integr. Comp. Biol. 43, $104-113$.

Zambrano, J.J., 1980. Comarca de la cuenca cretácica del Colorado. $2^{\circ}$ Simposio Geología Regional Argentina. Academia nacional de ciencias de Córdoba, 2. IO33 .1070 . 